Articles

$7-2006$

\title{
Emerging Definitions of Leadership in Higher Education
}

Pamela L. Eddy

College of William \& Mary, pamela.eddy@wm.edu

Kim E. VanDerLinden

StudentVoice

Follow this and additional works at: https://scholarworks.wm.edu/articles

Part of the Community College Leadership Commons, and the Educational Leadership Commons

\section{Recommended Citation}

Eddy, Pamela L. and VanDerLinden, Kim E., "Emerging Definitions of Leadership in Higher Education" (2006). Articles. 60.

https://scholarworks.wm.edu/articles/60

This Article is brought to you for free and open access by W\&M ScholarWorks. It has been accepted for inclusion in Articles by an authorized administrator of W\&M ScholarWorks. For more information, please contact scholarworks@wm.edu. 


\title{
Running Head: New visions of leadership
}

\begin{abstract}
The higher education literature suggests that alternative leadership styles are replacing the traditionally held definitions of leadership and provide new and different (and possibly superior) ways to understand leadership. This article looks for parallels within current leadership literature to see if community colleges administrators used the alternative language or emerging definitions of leadership to self-describe their own leadership, or if their self descriptions fit the more traditional hierarchical ideal of the positional or 'hero' leader.
\end{abstract}

\section{Emerging Definitions of Leadership in Higher Education: New Visions of Leadership or Same Old 'Hero' Leader?}

Challenges and opportunities exist simultaneously in the administrative and leadership ranks of our colleges and universities. The current context of higher education is shaped by the decline of institutional resources (Johnstone, 1999), changing student demographics (Hurtado \& Dey, 1997), shifts in teaching to student centered learning (Barr \& Tagg, 1995), the impact of technology on faculty roles (Baldwin, 1998), and the paradigm shift from an industrial age to an information age (Dolence \& Norris, 1995). The historical demand-response nature of community colleges pushes for strategic responses on the part of leaders (Gumport, 2003).

While the calls for leadership to address challenges and take advantage of opportunities are not new, the emerging definitions of what it means to be an institutional leader or what it means to practice leadership are changing.

Throughout the last half of the $20^{\text {th }}$ century, scholars spent considerable time postulating the requirements for and definitions of leadership. A scan of recent books published in higher education literature suggests that an interest in leadership continues to prevail (see for example, Astin \& Astin, 2000; Bowen \& Shapiro, 1998; Chliwniak, 1997; Davis, 2003; Nidiffer, 2001). In addition to investing much time and energy studying leadership in the academy, colleges and 
universities, as well as local, state, and national associations and organizations have devoted valuable resources to fund and send campus members to leadership training workshops and programs. In 2003, for example, the American Association of Community Colleges offered a Future Leaders Institute. The Institute targeted Vice Presidents, Deans, and Directors and had the stated objectives of instilling the skills, knowledge, and attitudes necessary for successful leaders. Yet with all these expended resources and pursuits, a question remains: Have the traditionally held definitions of leaders and leadership changed substantially within the ranks of actual administrative leaders?

The literature suggests that alternative leadership styles are replacing the traditionally held definitions of leadership and provide new and different (and possibly superior) ways to understand leadership. According to Davis (2003), leadership has been recognized as an activity that can "bubble up" in various places within institutions and no longer is only focused on formal leadership roles. Discussions of leadership throughout the organization (Peterson, 1997), team leadership (Bensimon \& Neumann, 1993), servant leadership (Greenleaf, 1977; Spears \& Lawrence, 2003), transformative leadership (Burns, 1978), inclusive leadership (Helgesen, 1995), and the role of followership (Kelley, 1998) have replaced the traditional discussions of the 'great man' or 'hero' leader.

To fully embrace alternative definitions of leadership demands rethinking the traditional images and the traditional relationships associated with leaders and followers (Green, 1997). Central to this rethinking is the transition from theoretical discussions of appropriate leadership to the actual practice of leadership at colleges and universities. To that end, this article looks for parallels within current leadership literature to see if community colleges administrators used the alternative language or emerging definitions of leadership to self-describe their own leadership, 
or if their self descriptions fit the more traditional hierarchical ideal of the positional or 'hero' leader.

\section{Literature Review}

The literature on leadership is as plentiful as it is diverse. The following review provides a general overview of theories of leadership and then a more specific review of the literature on community college leadership. A presentation of literature relating to gender and leadership, as well as leadership throughout the organization provides a context for investigating the particular research questions in this study.

\section{Theories about Leadership}

Several definitions of leadership, as well as theories of leadership exist in the literature. Some authors strive for a concise and clean definition and understanding of leadership. For example, according to Davis (2003) the term leadership implies movement, taking the organization or some part of the it in a new direction, solving problems, being creative, initiating new programs, building organizational structures, and improving quality (p.4). Others, however, struggle with the complexity of leadership. Bass and Stogdill (1990) reported on over 3000 empirical investigations of leadership, which provided varied conceptions of what leadership means. In light of the lack of precision regarding leadership definitions Birnbaum (1992) offered, “Any comprehensive consideration of academic leadership must be able to accommodate both the strong leader and the weak leader views, because evidence suggests that while both may be incomplete, both are in some measure correct" (p. 8). 
Rost (1991) noted that traditional leadership scholars and the theories they developed were concerned with the peripheries of leadership, such as traits, personality characteristics, and whether leaders are born or made. Rost went on to explain that leadership scholars are interested in the components of leadership and what leaders need to know in order to be influential in an organization. Less research has been "aimed at understanding the essential nature of what leadership is, and the processes whereby leaders and followers relate to one another to achieve a purpose" (p.4). In the post-industrial era, Rost argued that change would be undergirded by values such as collaboration, common good, global concern, diversity and pluralism in structures and participation, client orientation, civic virtues, freedom of expression in all organizations, critical dialogue, qualitative language and methodologies, substantive justice, and consensus oriented policy-making processes. An understanding of leadership within the realm of higher education relies upon the spectrum of various leadership theories purported over time and across disciplines.

Bensimon, Neumann, and Birnbaum (1989) completed a comprehensive exploration of the theories and models of leadership within higher education. These authors classified the theories into the following six categories: trait theories, power and influence theories, behavioral theories, contingency theories, cultural and symbolic theories, and cognitive theories. In early discussions of leadership, definitions and understandings coalesced around the nineteenth century notion of the 'great men' and their impact on society (Heifetz, 1994). In higher education the 'great men' at the turn of the twentieth century included such notables as Henry Tappan of the University of Michigan, Charles Eliot of Harvard, Andrew White of Cornell University, and Daniel Coit of Johns Hopkins University (Geiger, 1998; Rudolf, 1990). Trait 
theory explained leadership by the internal qualities with which a person was born (Stogdill, 1948).

Power and influence theories of leadership, in comparison, consider both the influence of leaders on followers as well as the reciprocal relationships between leaders and followers (Bensimon, Neumann, \& Birnbaum, 1989). Several authors (Fisher, 1984; Kelman, 1961) have reported on the charismatic power of the college president in influencing campus members, while noting the process of social influence. Social influence follows the stages of compliance, identification, and internalization. Within the context of higher education and the college presidency, compliance occurs when a campus member accepts the influence of the president because they hope the president will then view them favorably. Identification, on the other hand, occurs when the campus member seeks to emulate the behavior of the leader and is concerned with meeting the leader's expectation for role performance. Finally, internalization happens when the campus member accepts the influence of the leader because it is congruent with her or his own value system (Kelman, 1961).

Transactional and transformational leadership is based on the shared nature of the relationships between leaders and followers (Burns, 1978). Transactional leadership occurs when one person takes the initiative in making contact with others for the purpose of an exchange of something that is valued. Transformational leadership is based on more than the compliance of followers. It involves shifts in the beliefs, the needs, and the values of followers (Bensimon, Neumann, \& Birnbaum, 1989).

Behavioral theories of leadership look at what successful leaders do, rather than how they look to others. The Ohio State leadership studies (Stogdill \& Coons, 1957) and the Michigan Studies (Likert, 1961) used this approach in investigating leadership. The research at Ohio State 
University focused on identifying leader behaviors using the Leader Behavior Description Questionnaire (LBDQ). The resulting two-dimensional grid developed from this research focused on a leader's consideration for subordinates and the leader's focus on performance goals. Likewise, the Michigan studies identified two factors of influence; production-centered leaders emphasized employee tasks and means of accomplishing them, whereas employee-centered leaders focused on employee needs and interpersonal relationships. The ideal was to identify behaviors of leaders so that these behaviors in turn could be taught to others. Described as a series of dichotomies or continua, behaviorists focus on concepts like authoritarian versus democratic and task/structure versus relationship actions. An effective leader by behaviorist standards maintains a balance between perspectives, drawing on certain behaviors over others as the circumstances demand.

Contingency theorists argue that leaders adapt their leadership style to match the events at hand (Fiedler, 1967). This theory opened the possibility that leadership could be different in every situation (Horner, 1997). Alternatively, cultural and symbolic theories rely less on altering situational variables or drawing on particular kinds of interactions and more on the management of meaning and interpretation of the situation for others (Neumann, 1995).

Cognitive theories of leadership provide links between leaders and institutional outcomes (Birnbaum, 1992). Research (Amey, 1992; Fairhurst \& Sarr, 1996; Kuhnert \& Lewis, 1989) suggests that how leaders make meaning for themselves affects how they will make meaning for the organization. 
Community colleges, perhaps more so than four-year institutions, are facing what some call a leadership crisis, as some 79 percent of two-year college presidents plan to retire in the next eight years (Evelyn, 2001; Schults, 2001; Weisman \& Vaughan, 2002). This projected rapid turnover in administrative positions, however, presents an opportunity to "bring in fresh blood at a time when two-year colleges face increasingly complex demands" (Evelyn, 2001, p.36) and may present an opportunity to embrace new and emerging definitions and enactments of leadership.

The historical development of community colleges from the establishment of the first community college in Jolliet, Illinois in 1901 (Cohen \& Brawer, 2003) to the birth of the modern day community college in the 1960 s provides a shorter history and research literature from which to draw information. Like general theories on leadership, however, leadership at community colleges follows similar trends in the models and theories of what it means to be a campus leader. Twombly (1995) reviewed four eras of community college leaders, including the period from 1900-1930s in which the "great man" theory dominated; the 1940s-1950s in which leaders sought to become independent from secondary schools and forge an identity of their own; 1960s1970s in which the present day version of the community college was born with strong, dominate leadership that was necessary during those pioneering days; and the 1980s-2000 where attention to resource issues was more necessary and models from business began to be used that emphasized efficiency and strategic planning (Rowley \& Sherman, 2001).

Vaughan's (1986) book, The Community College Presidency, provided a profile of leaders of two-year institutions. This portrait of the presidency stressed qualities of community college presidents including: integrity, judgment, courage, and concern for others (p. 4). At the time of Vaughan's writing in the late 1980s, presidents and other constituents were just 
beginning to discuss the roles of subordinates and the importance of relationships. By 1989, Vaughan was writing about leadership in transition at community colleges. His work began to move beyond the personal descriptions of presidential traits to acknowledge the change from the "builder" presidents at community colleges to a leader with a broader range of duties. In this 1989 book women and minority presidents are acknowledged for having a role in community college leadership, thus marking and acknowledging a change in the demographic profile of community college presidents. In 1991, for example, 89 percent of community college presidents were males and 11 percent were minorities. A decade later this percentage shifted as 28 percent of presidents were women and 14 percent of presidents were people of color (Weisman \& Vaughan, 2002).

Building on the research by Bass (1985) and Burns (1978) that argued transformational leaders sought to heighten followers' awareness about issues of consequence and change follower's' goals and beliefs, Roueche, Baker, and Rose (1989) examined and categorized exemplary community college leaders using transformational behavioral attributes. Roueche, et al. used five themes for analysis, that transformative leaders believe in teamwork and shared decision-making, that they value people, both as members of the team and as individuals, that they understand motivation, that they have a strong personal value system, and finally, that they have a vision of what their college can become (p. 12). They concluded leaders were most effective when they empower others.

During the turbulent 1990s community colleges faced a decline in economic resources, a change in student composition with more adults turning to the community college for their educational needs, and a push to offer more community development programming. These forces necessitated a different kind of community college leader. Baker and Associates (1992) argued 
New visions of leadership -9-

for cultural leadership, recognizing the interdependence of organizational culture and leadership. Their research draws from leadership theory based on culture and symbolic management of meaning by college presidents. "The actions and utterances of leaders frame and shape the context of action in such a way that the members of that context are able to use them meaning thus created as a point of reference for their own action and understanding of the situation" (Smircich \& Morgan, 1982, p. 261). How leaders help create meaning for others in a given cultural context is at the heart of cultural leadership.

In the late 1990s, many community colleges embraced the concept of the learning college (O’Banion, 1997). Conceptions of leadership under this organizational paradigm calls for shared leadership; “It means embracing organizational learning so leadership will be a responsibility shared by all members based on understanding, competence, and creativity" (Gratton, 1993, p. 103). One manifestation of shared leadership involves conceptions of shared governance. Lucey (2002) argued that in shared governance institutional members have specific roles, namely faculty are responsible for academic and curricula issues and decisions and administrators are accountable for institutional strategy and decisions regarding resource allocation. Shared leadership calls for followers to be active and accountable.

The recognition of the role of followers and shared leadership argues for new conceptualizations of what it means to be a community college leader. The shift from early founder to multi-task manager requires an emphasis on communication, restructuring of organizational reporting and responsibilities, and a call for accountability (Lewis, 1989). Shifts in decision making over time from within the exclusive domain of the president, to a more participatory process involving shared governance reflect changes in community college leadership. 


\section{Gender and Leadership}

At community colleges, women currently comprise approximately 28 percent of all chief executive officer (CEO) positions. Women also represent 21 percent of Deans of Instruction (or similarly titled positions) positions at community colleges (Weisman \& Vaughan, 2002). Since the prime pathway to the presidency remains from the provost or the senior academic affairs administrator, it is likely that the future will show more women heading community colleges.

As noted above, conceptualizations of college presidents' approach to leadership has changed from the "take charge," "great man" approach to approaches emphasizing participatory and shared decision-making; approaches that are more often associated with women leaders (Chliwniak, 1997). DiCroce (1995) and Vaughan (1989a) suggest the following as ways in which women leaders can influence the culture of the community college and improve future opportunities for women: 1. Encourage the elimination of institutional gender stereotypes; 2. Redefine power and the power structure of the institution; 3. Enact gender-related policies and procedures; 4. Raise collegial consciousness and initiate collegial dialogue on gender and related issues; 5 . Take a proactive stance on public policy and debate beyond the local campus (as cited in Getskow, 1996, p. 2). As more women hold the top position on community college campuses, norms regarding the presidency and leadership will begin to change.

Literature on women's leadership assumes more sharing of power and a participatory orientation to leading (Chliwniak, 1997; Townsend \& Twombly, 1998) Townsend and Twombly argued, however, that a feminist orientation toward leadership at the community college must be centered on attention to women's issues and needs versus general campus issues. Glazer-Raymo (2003) contends that in analyses, gender needs to be considered as an analytic category versus 
merely a demographic variable to begin to formulate policy that really addresses the needs of women.

\section{Leadership Throughout the Organization}

New conceptions of "leadership look at leadership as a process in which leaders are not seen as individuals in charge of followers, but as members of a community of practice" (Horner, 1997, p. 277). One model for this type of leadership is distributed leadership (Gronn, 2000).

Rather than leadership formed on a dualistic premise, the responsibility for leading the college is shared throughout the organization. Instead of a focus on the sole positional leader of the president, the interdependiencies of the relationship is emphasized, in which roles change over time. The modification of strict roles over time makes the differentiation between leader and follower increasingly arbitrary (Birnbaum, 1992).

Multidimensional leadership is "likely to be the result of a team effort or of participation at differing levels, rather than the capacity of a single individual" (Peterson, 1997, p. 154). Similarly, Helgesen (1995) conceptualizes leadership as a web, in which there is structure, but also an ever-evolving changing shape. The leader at the center of the web works on building consensus and valuing the parts of the web, in which the parts are built on relationships.

The emphasis on the learning organization (O’Banion, 1997) also supports new conceptions of leadership in which "presidents and senior administrative staff need to be comfortable with fluid organizational dynamics that promote continuous learning, rigorous analysis and creative responses at all levels of the organization" (Dever, 1997,p.62). Central to learning organization success is the involvement and feedback from followers within the organization. 
Although different authors use a variety of terms in describing leadership throughout the organization (e.g., shared leadership, distributed leadership, multidimensional leadership, web of inclusion, etc.), each has as its central tenant a lack of focus on the hierarchical leader in the organization. Instead, leadership is described more in terms of relationships and highlights equally the roles of followers in obtaining success in the organization.

\section{Research Questions}

As detailed above and according to recent rhetoric, the older top-down leadership style at community colleges is shifting to the newer learner- and community-based paradigms to better meet organizational demands (Myran, 1995). This article explores this shift and provides an understanding of how community college administrators describe themselves as leaders. Specifically, this article identifies how expanded conceptualizations of leadership in theory differ and correlate with leadership in practice.

The following research questions will be addressed:

1. How do community college administrators self-report their leadership role at their institutions?

2. Do female and male administrators use similar language and categories when describing themselves as leaders?

3. Do administrators have varying views of their leadership based on administrative position?

Addressing these questions will illuminate the challenge of applying the leadership rhetoric advanced in higher education discourses to the actual institutional settings in which leaders find themselves. 
Method

The data reported here comes from a national survey of community college administrators. The survey instrument consisted of thirty-four questions and was pilot tested with community college administrators, two peer reviewers, and a panel of experts from the American Association of Community Colleges (AACC). A stratified random sample of 1700 community college administrators across 14 position codes was drawn from the AACC data bank, providing representation by geographic location, urban and rural locale, and single and multi-campus sites. During early 2000, letters of introduction and survey packets were mailed; extensive electronic and phone follow-ups were conducted; and a second mailing was distributed yielding a response rate of 54 percent $(n=910)$ usable surveys.

For this study the question of interest was an open-ended question that asked administrators if they considered themselves to be leaders at their institutions and why. Of the survey respondents, 682 administrators responded to this question. Content analysis was used to analyze the responses. Content analysis is a research method that allows for the counting and tallying of categorized themes within data. Content analysis has been described as a systematic and replicable technique for compressing many words of text into fewer content categories based on explicit rules of coding (Stemler, 2001).

Emergent coding of the responses was used. Categories were established after some preliminary examination of the data. Following the steps outlined by Haney, Russell, Gulek, and Fierros (1998), the two researchers independently reviewed the responses and developed a set of categories that formed a checklist. The researchers then compared checklists in order to reconcile any differences between lists. After extensive discussion, the two checklists were consolidated 
and both researchers coded the responses independently. Inter-rater reliability was high (85\% agreement between the two reviewers).

Limitations of content analysis are that it is inherently reductive, especially when dealing with complex topics, and leads to some simplistic choices that may limit analysis. For example, many of the responses reviewed had more than one code, but for analysis purposes, we chose only the primary code.

\section{Findings}

\section{Research Question 1-Self-reporting of leadership role on campus}

Content analysis of the 682 responses resulted in 11 primary classifications of responses regarding categorization of leadership (see Table 1). Each category is discussed in more detail below with the corresponding percentages of responses that fell into that category.

\section{Insert Table 1}

\section{About Here}

The first category of responses exemplified the traditionally held definitions of leadership and related to positional leadership. Responses that fell into this category stated that the position required them to be leaders. Other respondents discussed making decisions within functional areas, fulfilling job responsibilities such as serving on important institutional committees, as well as discussing their years of experience in the position. Responses that typified this category included, "I am part of the Executive Committee of the college and I have major institutional responsibility" and "[I am a leader] by virtue of my position and my history of leadership here." Approximately 47 percent of responses fell within this classification.

A second category of responses related to initiating change, taking on the change agent role, or making the environment conducive for change. Some responses that illustrate this 
category are "I am a transformational change agent" and "I have taken on numerous new projects and am considered an innovator." Nine percent of responses were classified in the change category.

Providing vision and direction were the defining phrases in the third category of responses. Seven percent of responses spoke to vision including the following: "I set the tone, shape and communicate the visions, and position the college on critical issues" and "I am responsible for developing, cultivating, and implementing the institutional vision."

A similar percentage of respondents $(6.6 \%)$ indicated that they were leaders at their institutions because of the knowledge and expertise they possessed. Many of the responses that fell into this category spoke about personal mastery. Examples of such responses included the following: "I am recognized statewide for expertise in my field" and "I am called upon often for insight and recommendations."

Some respondents $(4.5 \%)$ believed that they were leaders because others saw them in that light and because they were trusted and respected on their campuses. As one respondent wrote, "My views and suggestions are received with respect." Another administrator wrote, "I have the trust and confidence of faculty and administrator."

Rather than indicating personal characteristics, approximately three percent of administrators when asked if they were leaders on campus discussed fulfilling the mission of the college. For example, one administrator wrote, "I play a key role in advancing the mission of the institution through my work." In a similar sentiment, another administrator wrote, "[I have the] ability to understand the mission and focus people and community towards the mission."

Although writings on empowerment abound in the literature, few administrators $(3.1 \%)$ discussed empowering others, mentoring, advocating for others, role modeling, or motivating 
others as reasons for why they were leaders at their institutions. One administrator explained, "I have been able to motivate and support faculty and colleagues to accomplish their goals." Another wrote, "I try to pull together the resources necessary for others to do their job."

A surprisingly small percentages of administrators (1.9\%) talked of team leadership. Examples of those who did included: "I am viewed as a leader who values participative decision-making and team approaches" and "I consider myself a team player who leads when appropriate."

Approximately two percent of respondents spoke of their influence, power, and authority as being reasons for why they were leaders at their institutions. For example, one administrator indicated, "I have power, influence, and respect." Similarly, another administrator explained, "I seem to be able to successfully influence faculty/staff."

Two percent of administrators focused solely on their success and their ability to get the job done as the reasons for why they were leaders at their institution. As one administrator explained, "I get things done for the college when I see a need - job description or not." Another administrator stated, "People look to me to make things happen. I do."

And finally, close to six percent of the respondents did not believe that they were leaders at their institutions. Many stated that they faced barriers to leadership or that they were too new in their positions of institutions to be leaders. One administrator wrote, "[It is] difficult if not impossible to be a leader at this institution unless you are a faculty member or came from faculty ranks." Another indicated, "My area of responsibility is secondary to primary mission of the institution," while another administrator stated, "I consider myself a colleague more than a leader." 


\title{
Research Question 2-Women and Men's descriptions of leadership
}

In dividing the coded data set based on gender the categorizations of responses showed no significant difference based on sex. Some qualitative differences, however, are worth noting (See Table 2).

\section{Insert Table 2}

\begin{abstract}
About Here
Although not statistically significant, a slightly higher percentage of men were more likely than women to describe their leadership based on their position and responsibilities $(49.2 \%$ of men compared to $45.1 \%$ women). As one male stated, "My title says I am supposed to be a leader." Likewise, women also referred to their positional location, but often in terms of their experience and roles of responsibilities, "Yes. I have a position with a great deal of responsibility and continue to be put into leadership positions on task forces and committees."

Another area with a slightly higher percentage of male responses was within the category of "me-centered." Men were more likely than women to describe their leadership with themselves as the focal point ( $3.3 \%$ of men compared to $1.7 \%$ of women). One male respondent said, "Yes, [I am a leader] because I have the ability to make things happen." On the other hand, a woman respondent in this category noted, "Yes, I get things done." While both of these responses are coded for "me-centered" the orientation of the male respondent is to his ability to influence others to make things happen, versus the woman respondent who is the person actually doing things.
\end{abstract}

In the category related to knowledge and personal mastery, a slightly higher percentage of women were more likely than men to consider themselves a leader given their expertise (8.0\% women compared to $6.1 \%$ men), although again, this difference was not statistically significant. 
One female respondent commented, "My advice is often sought, as are my skills." A male respondent in this area said, "I am considered an expert on technical education by upper administration and my peers in this institution and throughout the state." The adage of 'knowledge is power' provides the backdrop for this leadership definition. In the examples cited, the female leader focused on her skills, whereas the male response focused on his expertise.

Finally, while not representing a large portion of the sample, women were more likely to define their leadership based on their ability to collaborate and build teamwork (2.8\% women to $1.3 \%$ men). A female commented, "I try to bring consensus in our decisions - try to include people in decision-making process. I'm not afraid, however, to make an unpopular decision based on what is right." Similarly, one male leader wrote, "I am viewed as being a leader who values participative decision-making and team approaches. "

\section{Research Question 3-Varying views of leadership based on administrative position}

Differences in responses were measured among six different position categorizations: presidents/provosts; academic affairs; student affairs; occupational and continuing education; administrative areas (e.g., business affairs, institutional research, human resources, development); and learning resources/distance education (See Table 3). The significant differences in positional categorizations of responses are reported below, along with notable qualitative differences.

Insert Table 3

About Here 
New visions of leadership -19-

\section{Presidents/Provosts}

An historical trait of leadership is the ability to provide vision (Roueche, Baker, \& Rose, 1989). Presidents and provosts were more likely than administrators in the other positions to indicate that they provided vision and shaped the direction of the college, as close to 20 percent of presidential responses referenced vision in their responses to why they were leaders at their institutions. As one president stated "I provide a focused vision for the future." Another president commented "I have an overall vision of the college as integral to the community and have moved it successfully toward being recognized as such."

\section{Academic Affairs Administrators}

Academic affairs administrators were more likely than Presidents/Provosts and more likely than those in Administrative Areas (business affairs, institutional research, human resources, and development) to indicate in their responses that others saw them as leaders. As one Vice President of Academic Affairs answered "People react to me as if I am a leader." Some academic administrators referred both to their position in the administrative hierarchy as well as expectations placed on them by colleagues: "As [the] \#2 person at the college, a lot of people look to me fore guidance and expect me to provide leadership."

While not statistically significant, other identifying factors showed up differently for those responding from positions in academic affairs. Those administrators working in academic affairs indicated more often than presidents or provosts that they were a change agent $(10.7 \%$ compared to $4.7 \%)$. As one academic dean stated, "By nature I am a strategic planner and motivator. Both skills have resulted in change." Another director commenting, "I have 
New visions of leadership -20-

spearheaded several initiatives with success," captured the immediate connection between plans and actions.

Those in academic affairs also identified themselves more often than presidents or provosts as a leader due to their knowledge or mastery (6.9\% compared to $1.2 \%)$. As mid-level administrators, these employees' job function is tied more directly to particular tasks or functions, making mastery of an area a sought after leadership quality for those in charge. One director's comment, "I have led in my area of specialty," illustrates the idea that knowledge and mastery conveys leadership for these administrators. Finally, academic affairs respondents indicated that they were a leader because others see them as a leader $(8.4 \%$ compared to $1.2 \%$ for presidents and provosts).

\section{Student Affairs Administrators}

A relatively high percentage $(11.2 \%)$ of student affairs administrators indicated that they were change agents at their colleges. The day-to-day interaction student affairs personnel have with students may be a contributing factor for this high percentage. Being a change agent may be expected within student affairs as it is constantly necessary to make adjustments to meet student needs. As one Dean of Students commented, "I am a problem-solver and integrator." The bridge between student affairs and academic affairs highlights collaboration for student learning (Kezar, 2003), and this collaboration was reflected in some of the responses. According to a Dean of Students, "I am regularly involved in building momentum and clearing the path for new initiatives." The ability to quickly adapt to changing cultural norms and student development issues is key for student affairs employees. According to one Vice President of Student Affairs, 
New visions of leadership -21-

"I have the opportunity to go as far with new ideas/programs as I want. I'm encouraged to be innovative."

Occupational and Continuing Education Administrators

Occupational and continuing education administrators, as compared to the other positional categories, were very similar in their responses to the question "Do you consider yourself a leader at your institution." This group of administrators was more likely than Presidents and Academic Affairs administrators to indicate that they were not leaders at their institutions, however. One Vice President of Occupational Education stated, “Ours is a very autocratic institution where second level administrators do not have a voice in the administration of the institution." And one Director of Continuing Education noted "President's actions indicate he desires to be the only leader, others have difficulty asserting leadership."

Administrative Areas (Business Affairs, Institutional Research, Human Resources, and Development)

This group of administrative personnel had the highest percentage that indicated they were leaders because of their positions (although it was not statistically significant across most positions). Perhaps due to the nature of their work, this group of administrators readily referred to their positional duties: "I manage several key operations on campus"; "I am in a high profile position which requires me to plan and oversee events"; and "I direct institutional assessment planning; overall coordination of Title III grant, and am responsible for federal/state enrolment reporting." 
New visions of leadership -22-

\section{Learning Resources/Distance Education Administrators}

Those in charge of learning resources and distance education programs were more likely than the other position categories to indicate that they were not leaders at their institutions or that they were experiencing leadership barriers. Administratively, those located in this category are seemingly among the lower ranks of the hierarchy. One Director of Learning Resources noted, “...it is difficult if not impossible to be a leader at this institution unless you are a faculty member or came from faculty ranks." One Director of Distance Education commented "My area receives low priority." Individuals in this category perceived their positions as marginalized in the organization. Quite telling were the lack of respondents in this category using the selfdescriptors of setting the vision for the campus or for having influence or power. None of these administrators in these positions identified themselves using either of these descriptors.

\section{Discussion and Conclusion}

The findings from this research indicate that despite calls for new forms of leadership, the survey respondents still largely viewed themselves as leaders primarily due to their position. What is encouraging, however, is that while no other single definition of leadership ranked as high as position, cumulatively, the non-position responses, account for half of the descriptors. Thus, administrators are now conceiving of themselves as leaders using expanded ideals beyond just their position.

Few differences existed in how men or women defined their leadership. Where there were slight percentage differences based on gender, the male and female responses were captured in typically stereotypic ways. Namely, the view of male leadership as more directive and autocratic (based on position; me-centered) and female leadership as more participatory and 
valuing meritocracy as measured by value of knowledge (create environment for change; knowledge mastery; working for the good of the college). These findings suggest a need to think differently about gender and leadership. The weak differences found in defining leadership by gender underscores that gender is not always the defining variable of difference in how one chooses to lead. Rather, colleges may need to concentrate instead on institutional structures that may act as a barriers or impediments for the advancement of women (VanDerLinden, 2003).

Those in the position of president or provost were more likely to see themselves as shaping the direction of college. While being a visionary is often typically ascribed to these positional leaders, it is not without a cost. Pfeffer (1991) reported that presidents, as the positional leader on campus, were limited in the amount of power and control at their disposal. The findings reported here continue to bear out this claim. Administrators in academic affairs and those located at different levels in the administrative hierarchy perceive themselves as having more ability to enact change. Part of the reason for this finding may be that mid-level administrators have fewer areas of control in their domain and therefore can exert more influence on those areas actually within their control. Also, the president and provost roles are more publicly visible, both on campus and to the larger community. Actions taken by these positional leaders are more scrutinized and involve more political negotiation among competing parties.

Presidents and provosts were not likely to say they were leaders because others see them as such. Instead, the perception others have of these ultimate campus leaders was implicit based on their organizational chart positions at the top of the hierarchy. In general, presidents and provosts did not define their leadership using concepts of teams or empowering others. And it was student affairs personnel and those in learning resources who saw themselves most often as working to fulfill the mission of the college. These personnel perceived direct ties between their 
leadership and the work of the college. As visionary leaders, presidents and provosts again may have made assumptions about their leadership roles, assuming that their work inherently fulfills the mission of the college.

The findings related to positional differences indicate more variation amongst positions, as compared to gender differences. These findings raise interesting questions regarding the route to the presidency. Since fewer leadership differences were accounted for by gender and more by position, the question becomes, is it a person's position that elicits different conceptions of leadership? Viewing the findings by position indicated that along with additional influence as one moves up the administrative hierarchy, one also assumes additional limitations. Barriers were also perceived by those located further down the organizational hierarchy in learning resources or distance education. Barriers faced by these lower level administrators may be due to the marginalization of these organizational units in the college.

\section{Implications}

If community colleges truly want to embrace their heritage as democracy colleges, as well as the ideal of participatory leadership and leadership throughout the organization, organizational structures and the mindsets of leaders may need to change. Currently there is still a reliance on the bureaucratic and reporting hierarchy in how administrators see themselves as leaders. Given that more women are ascending to positions of power on campus, community colleges may witness a change. New definitions and models of what it means to lead a community college campus may become more apparent and move in the direction of increased emphasis on participation and team leadership. Based on the glimpse presented here, even 
though gender differences were not pronounced, where differences occurred, women valued more participation and were less focused on me-centered leadership.

The administrators responding to this survey are working at community colleges that have been previously described as bureaucratic in orientation (Birnbaum, 1992). Historically, this organizational orientation reifies and values positional leadership over other types. The question remains, have the structures of community colleges evolved to allow for and to support other conceptions of leadership? The findings from this research indicate a qualified "yes."

Many of the surveys responses provided more than one definition of leadership. The administrator's primary responses formed the basis of the findings reported here. The multiple coding of the responses, however, indicates that individuals are thinking more complexly about leadership, rather than merely attributing it to position or one characteristic. Providing ways to support expanded definitions of leadership is critical. Leadership development and training opportunities are an opportune time to nurture expanded conceptions of what it means to be a leader. And the expected leadership turnover in community colleges over the next decade provides such an opportunity for change. 


\section{References}

Amey, M. J. (1992, November). Cognitive constructions of leadership. Paper presented at the Annual Meeting of the Association for the Study of Higher Education, Minneapolis, MN.

Astin, A. \& Astin, H. (2000). Leadership reconsidered. Battle Creek, MI: Kellogg Foundation. ED 444437.

Baker, G. A., \& Associates. (1992). Cultural leadership: Inside America's community colleges. Washington, DC: American Association of Community and Junior Colleges.

Baldwin, R. G. (1998). Technology's impact on faculty life and work. In K. H. Gillespie (Ed.), The Impact on Technology on Faculty Development, Life, and Work, 7-21. San Francisco: Jossey-Bass.

Barr, R. B., \& Tagg, J. (1995). From teaching to learning-A new paradigm for undergraduate education. Change, 27(5), 12-25.

Bass, B. M. (1985). Leadership and performance beyond expectations. New York: Free Press.

Bass, B. M., \& Stogdill, R. M. (1990). Bass and Stogdill's handbook of leadership. (3 ${ }^{\text {rd }}$ ed.). New York: Free Press.

Bensimon, E. M., \& Neumann, A. (1993). Redesigning collegiate leadership: Teams and teamwork in higher education. Baltimore, MD: The Johns Hopkins University Press.

Bensimon, E. M., Neumann, A., \& Birnbaum, R. (1989). Making sense of administrative leadership: The "L" word in higher education. ASHE-ERIC Higher Education Report No. 1 ED 316074 MF-01. Washington DC: The George Washington University.

Birnbaum, R. (1992). How academic leadership works: Understanding success and failure in the college presidency. San Francisco: Jossey-Bass Publishers.

Bowen, W. \& Shapiro, H. (1998). Universities and their leadership. Princeton, NJ: Princeton University Press.

Burns, J. M. (1978). Leadership. New York: Harper \& Row.

Chliwniak, L. (1997). Higher education leadership: Analyzing the gender gap, ASHE-ERIC Higher Education Report, 25 (4). Washington DC: ASHE.

Cohen, A. M., \& Brawer, F. B. (2003). The American community college (4th ed.). San Francisco: Jossey-Bass Publishers.

Davis, J. (2003). Learning to Lead. Westport, CT: American Council on Education, Praeger Publishers. 
Dever, J. T. (1997). Reconciling educational leadership and the learning organization. Community College Review, 25(2), 57-63.

DiCroce, D. (1995). Women and the community college presidency: Challenges and possibilities. In B.K. Townsend (Ed.), Gender and Power in the Community College. New Directions for Community Colleges, no. 89. San Francisco: Jossey-Bass.

Dolence, M. G., \& Norris, D. M. (1995). Transforming higher education: A vision for learning in the 21st Century. Ann Arbor: Society for College and University Planning.

Evelyn, J. (2001). Community colleges face a crisis of leadership. The Chronicle of Higher Education, A36.

Fairhurst, G. T., \& Sarr, R. A. (1996). The art of framing: Managing the language of leadership. San Francisco: Jossey-Bass.

Fiedler, F. E. (1967). A theory of leadership effectiveness. New York: McGraw-Hill.

Fisher, J. L. (1984). Power of the presidency. New York: American Council on Education, MacMillan Publishing Company.

Geiger, R. L. (1998). The ten generations of American higher education. In P.G. Altbach, R. O. Berdahl, \& P. Gumport (Eds.), American higher education in the $21^{\text {st }}$ century (pp. 38-69). Baltimore: Johns Hopkins University Press.

Getskow, V. (1996). Women in community college leadership roles. ERIC digest. (ED400025). Los Angeles, CA: ERIC Clearinghouse for Community Colleges.

Glazer-Raymo, J. (1999). Shattering the myths: Women in academe. Baltimore, MD: The Johns Hopkins University Press.

Glazer-Raymo, J. (2003). Women faculty and part-time employment: The impact of public policy. In B. Ropers-Huilman (Ed.), Gendered futures in higher education: Critical perspectives for change, (pp. 97-110). Albany, NY: Statue University of New York Press.

Gratton, M. (1993). Leadership in the learning organization, in New Directions for Community Colleges, no. 84, pp. 93-103.

Green, M. (1997). No time for heroes. Trusteeship, 5(2), 6-11.

Greenleaf, R. K. (1977). Servant leadership: A journey into the nature of legitimate power and greatness. New York: Paulist Press. 
Gronn, P. (2000). Distributed properties: A new architecture for leadership. Educational Management \& Administration, 28(3), 317-38.

Gumport, P. J. (2003). The demand-response scenario: Perspectives of community college presidents. In K.M. Shaw \& J.A. Jacobs (Eds.), Community Colleges: New Environments, New Directions (38-61). The Annals of the American Academy of Political and Social Science, Thousand Oaks, CA: Sage Publications.

Haney, W., Russell, M., Gulek, C., \& Fierros, E. (1998). Drawing on education: Using student drawings to promote middle school improvement. Schools in the Middle, 7(3), 38-43.

Heifetz, R. A. (1994). Leadership without easy answers. Cambridge: The Belknap Press of Harvard University Press.

Helgesen, S. (1995). The web of inclusion: A new architecture for building great organizations. New York: Currency/Doubleday.

Horner, M. (1997). Leadership theory: Past, present, \& future. Team Performance Management, 3(4), 270-287.

Hurtado, S., \& Dey, E. L. (1997). Achieving the goals of multiculturalism and diversity. In M. Peterson, D. D. Dill, L. Mets, \& Associates (Eds.), Planning and management for a changing environment, pp. 405-431. San Francisco: Jossey-Bass.

Johnstone, D. B. (1999). The challenge of planning in public. Planning for Higher Education, 28(2), 57-64.

Kelley, R. E. (1998). In praise of followers. In W. Rosenbach \& R. L. Taylor (Eds.), Contemporary issues in leadership, 4th Edition , 96-106. Boulder, CO: Westview Press.

Kelman, H. (1961). Process of opinion change. Public Opinion Quarterly, 25(1), 57-78.

Kezar, A. (2003). Achieving student success: Strategies for creating partnerships between academic and student affairs. NASPA Journal, 41(1), 1-22.

Kuhnert, K. W., \& Lewis, P. (1989). Transactional and transformational leadership: A constructive/developmental analysis. In W. E. Rosenbach \& R. L. Taylor (Eds.), Contemporary issues in leadership ( $2^{\text {nd }}$ ed., pp. 192-206). Boulder: Westview Press.

Lewis, M. D. (1989) Effective leadership strategies for the community college president. Long Beach City College, CA ED307948

Likert, R. (1961). New patterns of management. New York: McGraw-Hill.

Lucey, C. A. (2002). Civic engagement, shared governance, and community colleges. Academe, 88(4), 27-31. 
New visions of leadership -29-

Myran, G. (1995). Community College leadership in the new century: Learning to improve learning. Washington, DC: American Association of Community Colleges.

Neumann, A. (1995). On the making of hard times and good times. Journal of Higher Education, 66(1), 3-31.

Nidiffer, J. (2001). New leadership for a new century. In J. Nidiffer and C. Bashaw (Eds.). Women administrators in higher education, 101-131. Albany: State University of New York Press.

O'Banion, T. (1997). A learning college for the $21^{\text {st }}$ century. Phoenix, AZ: American Council on Education Oryx Press Series on Higher Education.

Pfeffer, J. (1991). The ambiguity of leadership. In M. Peterson (Ed.), Organization and Governance in Higher Education (4th ed., pp. 345-354). Needham Heights, MA: Simon $\&$ Schuster Custom Publishing.

Peterson, M. (1997). Using contextual planning to transform institutions. In M. Peterson, D. Dill, L. A. Mets, \& Associates (Eds.), Planning and management for a changing environment, 127-157. San Francisco: Jossey-Bass Publishers.

Roueche, J. E., Baker, G. A., III, \& Rose, R. R. (1989). Shared vision: Transformational leadership in American community colleges. Washington, DC: The Community College Press.

Rost, J. C. (1991). Leadership for the Twenty-first Century. New York: Praeger Publishers.

Rowley, D. J., \& Sherman, H. (2001). From strategy to change: Implementing the plan in higher education. San Francisco: Jossey-Bass.

Rudolf, F. (1990). The American college \& university: A history. Athens: The University of Georgia Press.

Schults, C. (2001). The critical impact of impending retirements on community college leadership. American Association of Community Colleges Press.

Smircich, L., \& Morgan, G. (1982). Leadership: The management of meaning. The Journal of Applied Behavioral Science, 18(3), 257-273.

Spears, L.C., \& Lawrence, M. (Eds.). (2003). Focus on leadership: Servant-leadership for the twenty-first century. San Francisco: Jossey Bass.

Stemler, S. (2001). An introduction to content analysis. College, Park, MD: ERIC Clearinghouse on Assessment and Evaluation. 
Stogdill, R. M. (1948). Personal factors associated with leadership: A survey of the literature. Journal of Psychology, 25, 35-71.

Stogdill, R. M., \& Coons, A. E. (Eds.). (1957). Leader behavior: Its description and measurement. Columbus, OH: Bureau of Business Research, Ohio State University.

Townsend, B. K., \& Twombly, S. B. (1998). A feminist critique of organizational change in the community college. In. J. S. Levin (Ed.), Organizational change in the community college: A ripple or a sea change?, pp. 77-85. New Directions for Community Colleges. San Francisco: Jossey-Bass Publishers.

Twombley, S. B. (1995). Gendered images of community college leadership: What messages they send. New Directions for Community Colleges, 23(1), 67-77.

Weisman, I. M., \& Vaughan, G. B. (2002). The community college presidency, 2001. AACC Research Brief. Washington, DC: American Association of Community Colleges.

VanDerLinden, K. (2003, April). Career advancement and leadership development of community college administrators. Paper presented at the Annual Meeting of the American Educational Research Association, Chicago, IL.

Vaughan, G. B. (1986). The community college presidency. Washington, DC: American Council on Education.

Vaughan, G. (1989a). Female community college presidents. Community College Review, 17(2), 20-24.

Vaughan, G. B. (1989b). Leadership transition: The community college presidency. New York: American Council on Education, MacMillan Publishing Company. 
Table 1. Coding Scheme

Code

1

2

3

4

5

6

7

8

9

\section{Content}

Positional, Responsibilities, Committees, Decision-making Related to job function, Experience, Leader within area

Change agent, Initiate change, Create environment for change

Provide vision, Shape direction

Knowledge, Personal mastery, Expertise, Frequently Asked or consulted because of expertise, Other personal Traits

Others see me as a leader, People trust me and/or respect me

Fulfilling mission of the college, Working for the good of the organization

Empower others, Advocate for others, Provide support, Mentor, Motivate others, Role model, Set example

Me-centered, I am successful, I have the ability to make things happen

Teamwork, Inclusiveness, Collaboration, Building consensus

Influence, Power, Authority, Control financial resources

Not a leader, experiencing barriers to being a leader, or too new in the position to be a leader 
Table 2. Gender Differences in Primary Themes*

\begin{tabular}{|l|c|c|}
\hline \multicolumn{1}{|c|}{ Coding Theme } & $\begin{array}{c}\text { Percentage } \\
\text { Male } \\
\text { (N=396) }\end{array}$ & $\begin{array}{c}\text { Percentage } \\
\text { Female } \\
\text { (N=286) }\end{array}$ \\
\hline $\begin{array}{l}\text { Positional, responsibilities, committees, decision-making related to } \\
\text { job function, experience, leader within area }\end{array}$ & $49.2 \%$ & $45.1 \%$ \\
\hline Change agent, initiate change, create environment for change & 7.8 & 8.7 \\
\hline $\begin{array}{l}\text { Provide vision, shape direction } \\
\text { Knowledge, personal mastery, expertise, frequently asked or } \\
\text { consulted because of expertise, other personal traits }\end{array}$ & 7.1 & 7.0 \\
\hline $\begin{array}{l}\text { Others see me as a leader, people trust me and/or respect me } \\
\text { Fulfilling mission of the college, working for the good of the } \\
\text { organization }\end{array}$ & 5.1 & 4.5 \\
\hline $\begin{array}{l}\text { Empower others, advocate for others, provide support, mentor, } \\
\text { motivate others, role model, set example }\end{array}$ & 3.1 & 3.1 \\
\hline $\begin{array}{l}\text { Me-centered, I am successful, I have the ability to make things } \\
\text { happen }\end{array}$ & 3.3 & 1.7 \\
\hline $\begin{array}{l}\text { Teamwork, inclusiveness, collaboration, building consensus } \\
\text { Yes, but no explanation }\end{array}$ & 1.3 & 2.8 \\
\hline $\begin{array}{l}\text { Influence, power, authority, control financial resources } \\
\text { the position to be a leader }\end{array}$ & 6.8 & 2.8 \\
\hline
\end{tabular}

*No significant gender differences. 
Table 3. Position Differences in Primary Themes

\begin{tabular}{|c|c|c|c|c|c|c|}
\hline & $\begin{array}{c}\text { Presidents, } \\
\text { Provosts } \\
\quad \text { N=86 }\end{array}$ & $\begin{array}{c}\begin{array}{c}\text { Academic } \\
\text { Affairs }\end{array} \\
\text { N=131 } \\
\end{array}$ & $\begin{array}{c}\begin{array}{c}\text { Student } \\
\text { Affairs }\end{array} \\
\\
\mathbf{N}=98 \\
\end{array}$ & $\begin{array}{c}\text { Occupational } \\
\text { and } \\
\text { Continuing } \\
\text { Education } \\
\mathbf{N}=151 \\
\end{array}$ & $\begin{array}{c}\text { Admin Areas } \\
\text { (Business } \\
\text { Affairs, IR, HR, } \\
\text { Development) } \\
\text { N=162 } \\
\end{array}$ & $\begin{array}{c}\text { Learning } \\
\text { Resources/ } \\
\text { Distance } \\
\text { Education } \\
\mathbf{N}=\mathbf{5 4} \\
\end{array}$ \\
\hline $\begin{array}{l}\text { Positional, responsibilities, committees, decision-making } \\
\text { related to job function, experience, leader within area }\end{array}$ & $43.0 \%$ & $46.6 \%$ & $49.0 \%$ & $48.3 \%$ & $52.5 \%(1)$ & $37.0 \%(1)$ \\
\hline Change agent, initiate change, create environment for change & 4.7 & 10.7 & 11.2 & 9.3 & 5.6 & 7.4 \\
\hline Provide vision, shape direction & $19.8(2)$ & 8.4 & 4.1 & 3.3 & 6.8 & 0.0 \\
\hline $\begin{array}{l}\text { Knowledge, personal mastery, expertise, frequently asked or } \\
\text { consulted because of expertise, other personal traits }\end{array}$ & $1.2(3)$ & 6.9 & $9.2(3)$ & 6.6 & 8.6 & 7.4 \\
\hline Others see me as a leader, people trust me and/or respect me & $1.2(4)$ & $8.4(4)$ & 4.1 & 6.7 & $2.5(4)$ & 5.6 \\
\hline $\begin{array}{l}\text { Fulfilling mission of the college, working for the good of the } \\
\text { organization }\end{array}$ & 3.5 & 1.5 & 5.1 & 3.3 & 2.5 & 5.6 \\
\hline $\begin{array}{l}\text { Empower others, advocate for others, provide support, } \\
\text { mentor, motivate others, role model, set example }\end{array}$ & 1.2 & 3.8 & 2.0 & 3.3 & 3.7 & 3.7 \\
\hline $\begin{array}{l}\text { Me-centered, I am successful, I have the ability to make } \\
\text { things happen }\end{array}$ & 4.7 & 0.8 & 2.0 & 2.6 & 3.1 & 3.7 \\
\hline Teamwork, inclusiveness, collaboration, building consensus & 2.3 & 3.1 & 1.0 & 0.7 & 1.9 & 3.7 \\
\hline Influence, power, authority, control financial resources & 3.5 & 1.5 & 1.0 & 4.0 & 0.6 & 0.0 \\
\hline Yes, but no explanation & 14.0 & 6.9 & 6.1 & 3.3 & 7.4 & 5.6 \\
\hline $\begin{array}{l}\text { Not a leader, experiencing barriers to being a leader, or too } \\
\text { new in the position to be a leader }\end{array}$ & $1.2(5)$ & $1.5(5)$ & 5.1 & $8.6(5)$ & 4.9 & $20.4(5)$ \\
\hline
\end{tabular}

(1) Administrative areas were significantly more likely than Learning Resources/Distance Education to indicate positional, responsibilities, etc... $(\mathrm{p} .=.041)$

(2) Presidents were significantly more likely to indicate provide vision, shape direction (p.<.05 for each position category) 
(3) Student Affairs administrators were more likely than Presidents/Provosts to indicate knowledge, personal mastery, expertise, etc... (p. $=.021)$

(4) Academic Affairs administrators were more likely than Presidents/Provosts (p.=.03) and more likely than those in Administrative Areas ( $\mathrm{p} .=.03$ ) to indicate that others see them as leaders.

(5) In all instances, Learning Resources/Distance Education administrators were more likely to indicate that they were not leaders at their institutions. Those in administrative areas were also more likely than Presidents/Provosts (p.=.021) or Academic Affairs administrators (p.=.008) to indicate that they were not leaders. 